\title{
Comparison of Ammonium-oxidizing Bacterial Community Changes in Sludges from a Sewage and a Marine Fish Market Wastewater Treatment Plant During Enrichment Cultivation Under High Saline Conditions
}

\author{
Jeongmi Kim ${ }^{\oplus} \cdot{\text { Jaecheul } \mathbf{Y u}^{\oplus} \cdot \text { Soyeon Jeong }}^{\oplus} \cdot$ Yeonju Kim $^{\oplus} \cdot$ Hyokwan Bae $^{\oplus} \cdot$ Taeho Lee $^{\dagger}$ \\ Department of Civil and Environmental Engineering, Pusan National University
}

(Received November 25, 2020; Revised January 5, 2021; Accepted January 11, 2021)

Objectives: It is important to enrich and cultivate ammonia oxidation bacteria (AOB) in order to successfully treat nitrogen in high saline wastewater using a deammonification process. Two different inocula, a sewage sludge and a fish-market wastewater sludge, were cultivated to enrich $\mathrm{AOB}$ and compared the changes of microbial community.

Methods: A sequential batch reactor (SBR) inoculated with the sewage sludge (PN1) enriched AOB under high-strength ammonium condition $\left(500-3,000 \mathrm{mg} \mathrm{NH}_{4}{ }^{+} \mathrm{-N} / \mathrm{L}\right)$ and then the salt concentration in the medium was gradually increased up to $20 \mathrm{~g}-\mathrm{NaCl} / \mathrm{L}$. The other SBR seeded with the fish market wastewater sludge (PN2) was operated to enrich $\mathrm{AOB}$ directly under $20 \mathrm{~g} \mathrm{NaCl} / \mathrm{L}$ without any acclimation step.

Results and Discussion: Both PN1 and PN2 successfully showed more than $60 \%$ of the nitrite accumulation efficiency at a high saline concentration of $20 \mathrm{~g} \mathrm{NaCl} / \mathrm{L}$. At the level of the phylum, Proteobacteria containing nitrifying microorganisms became dominant in both PN1 and PN2. However, the most dominant bacterial species in PN1 and PN2 were Nitrosomonas eutropha (60.7\%) and N. halophila (20.2\%), respectively.

Conclusions: Although different results of the most abundant AOB were shown in both sewage sludge and fish-market wastewater sludge conditions, nitritation was successfully developed even with wastewater containing high salinity. Therefore, in this study, both sludges can be applied for inoculation to the PN process for efficiently treating wastewater with high concentration of ammonium and saline.

Keywords: Ammonia Oxidizing Bacterial Community, Deammonification, High-strength Ammonium, High-saline Wastewater, Inoculum Sources

The Korean text of this paper can be translated into multiple languages on the website of http://jksee.or.kr through Google Translator. 


\title{
연구논문
}

\section{고염분 조건의 농화배양 과정에서 하수슬러지와 염분폐수슬러지의 아질산화 미생물군집 변화 비교}

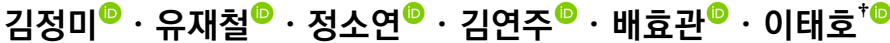

부산대학교 사회환경시스템공학과

목적: 탈암모니아 공정을 이용하여 고농도 염분폐수의 질소를 성공적으로 처리하기 위해서는 아질산화 미생물 의 농화배양이 중요하다. 본 연구에서는 하수처리장 슬러지(하수슬러지)와 공동어시장의 폐수처리장 슬러지(염 분폐수슬러지)를 각각 식종원으로 이용하여 고농도 염분 조건의 농화배양 과정에서 발생하는 암모늄 산화 미생물 (Ammonia oxidizing bacteria, AOB)군집 변화를 비교하고자 하였다.

방법: 하수슬러지를 식종한 PN1 반응기에서는 고농도의 암모늄 $\left(500-3,000 \mathrm{mg} \mathrm{NH}{ }_{4}{ }^{+} \mathrm{N} / \mathrm{L}\right)$ 을 아질산염으로 전환할 수 있는 $\mathrm{AOB}$ 를 먼저 농화배양하였으며, 이후 염분농도를 단계적으로 $20 \mathrm{~g} \mathrm{NaCl} / \mathrm{L}$ 까지 증가시켰다. 염분폐수슬러 지를 식종한 PN2 반응기에서는 순응 단계 없이 곧바로 염분농도 $20 \mathrm{~g} \mathrm{NaCl} / \mathrm{L}$ 에서 $\mathrm{AOB}$ 를 농화배양하였다.

결과 및 토의: PN1과 PN2 반응기 모두 염분농도 $20 \mathrm{~g} \mathrm{NaCl} / \mathrm{L}$ 에서 고농도의 암모늄을 $60 \%$ 이상 아질산염으로 전환하였 다. 미생물군집분석 결과, 문(phylum) 수준에서는 두 반응기 모두에서 질산화 관련 미생물이 속하는 Proteobacteria가 우점하는 것으로 나타났다. 하지만, 종(species) 수준에서는 PN1에서 Nitrosomonas eutropha (60.7\%)가, PN2에서 N. halophila $(20.2 \%)$ 가 각각 우점하였다.

결론 : 하수슬러지와 염분폐수슬러지에서 우점하는 $\mathrm{AOB}$ 는 다르게 나타났지만, 두 슬러지 모두 고염분 조건에서 $\mathrm{PN}$ 공정을 성공적으로 구축할 수 있었다. 따라서, 두 슬러지 모두 고염분 환경에서 암모늄을 처리하는 PN 공정 구축을 위한 식종원으로 사용할 수 있을 것이다.

주제어: 고염분 폐수, 고농도 암모늄, 식종원 슬러지, 아질산화 미생물군집, 탈암모늄 공정

\section{1. 서론}

음폐수, 수산물 가공, 섬유 염색, 석유화학 및 가스생산 공정 폐수 등 고농도 암모늄과 고농도 염분을 동시에 함유한 폐수 의 발생량이 증가하고 있다. 예를 들어, 음식물류 폐기물의 처리 및 재활용 과정에서 음식물류 폐기물의 $50-70 \%$ 가 음폐 수로 발생되고, 음폐수의 대부분은 혐기성 소화처리되고 있으 나, 혐기소화처리공정에서 발생하는 유출수는 고농도의 염분 $(20 \mathrm{~g} \mathrm{NaCl} / \mathrm{L})$ 과 질소 $\left(2,000 \mathrm{mg} \mathrm{NH}{ }_{4}{ }^{+}-\mathrm{N} / \mathrm{L}\right)$ 를 함유하고 있는 데, 해양 배출이 금지됨에 따라 연계 처리를 위한 공공하수처 리시설 또는 침출수처리시설에 큰 부담이 되고 있다. ${ }^{1-4)}$ 특히 고농도의 염분은 삼투압 현상을 유발하여 세포 내 수분이 배 출됨에 따라 미생물의 활성이 저하되고, 결과적으로 생물학적 인 폐수 처리효율을 감소시킨다. ${ }^{5-8)}$

고농도의 암모늄을 효율적으로 처리할 수 있는 생물학적 공정으로서 탈암모늄 공정이 주목받고 있다. 탈암모늄 공정은
기존 질산화-탈질 공정과 달리 외부 탄소원이 필요하지 않 고, 폭기 비용을 $60 \%$ 절감할 수 있으며, 슬러지 발생량도 최대 $90 \%$ 까지 절감할 수 있는 경제적인 질소제거 공정이다. ${ }^{9-11)}$ 탈암모늄 공정은 암모늄 산화 미생물(Ammonia oxidizing bacteria, $\mathrm{AOB}$ )에 의하여 암모늄의 약 $50 \%$ 가 아질산염으로 전환되는 부분 아질산화 반응(Partial nitritation; PN)과 혐기 성 암모늄 산화 미생물에 의하여 암모늄과 아질산염이 $\mathrm{N}_{2}$ 가 스로 전환되는 아나목스반응(Anaerobic ammonium oxidation; ANAMMOX)으로 구성된다. ${ }^{12-14)}$ 따라서 성공적으로 염분폐 수를 처리하기 위한 탈암모늄 공정을 구축하기 위해서는 $\mathrm{AOB}$ 가 우점하는 아질산화 미생물군집을 농화배양하고 염분에 순 응시키는 과정이 반드시 필요하다.

특히, 고염분의 폐수 처리를 위한 PN 공정을 구축하기 위해서는 염분에 내성이 있는 $\mathrm{AOB}$ 의 활성을 안정적으로 유지하고, 아질산 염 산화 미생물(Nitrite oxidizing bacteria; $\mathrm{NOB}$ )의 활성을 억제 하는 것이 필요하다. ${ }^{15)} \mathrm{AOB}$ 는 Betaprotebacteria에 포함되는 
Nitrosomonas 속 및 Nitrosospira 속과 Gammaproteobacteria에 포함되는 Nitrosococcus 속으로 구분할 수 있다. ${ }^{16,17)}$ 일반적으로 $\mathrm{AOB}$ 는 다양한 염분농도에서 서식하며, 염분 내성에 따라서 강호 염성 AOB (Nitrosomonas marina, N. aestuarii, N. cryotolerans, N. halophilus, Nitrosococcus oceani), 내염성 또는 중호염성 $\mathrm{AOB}$ (N. europaea, N. eutropha, N. halophila, N. mobilis)로 구분할 수 있다. ${ }^{18-20)}$

일반적으로 염분폐수 처리를 위한 PN 공정을 구축하기 위 해서, 하수슬러지를 식종원으로 이용하여 아질산화 반응을 먼저 유도한 후에 염분 농도를 단계적으로 증가시켜 순응시키 거나, 염분에 먼저 순응시킨 후에 아질산화 반응을 유도하는 방법이 사용된다. Wan 등 ${ }^{21)}$ 은 일반 하수슬러지를 식종원으로 이용하는 호기성 그래뉼 반응기에서 염분 농도를 $15 \mathrm{~g} \mathrm{NaCl} / \mathrm{L}$ 에서 $50 \mathrm{~g} \mathrm{NaCl} / \mathrm{L}$ 까지 단계적으로 증가시켰을 때, $90 \%$ 이상의 아질산염 축적율을 유지하였다고 보고하였다. Moussa 등 ${ }^{22)}$ 은 염분(16.5 g NaCl/L)에 순응된 하수슬러지와 염분에 순응되지 않은 하수슬러지를 이용하여, 염분농도를 $66 \mathrm{~g} \mathrm{NaCl} / \mathrm{L}$ 까지 단계적으로 증가시켜 운전하였다. 염분 순응에 상관없이 16.5 $\mathrm{g} \mathrm{NaCl} / \mathrm{L}$ 에서는 $\mathrm{AOB}$ 의 활성도가 $35 \%$ 감소하였으며, $66 \mathrm{~g}$ $\mathrm{NaCl} / \mathrm{L}$ 에서는 $95 \%$ 까지 감소한다고 보고하였다. 이처럼, 일반 하수슬러지를 식종원으로 이용하면, 염분 순응을 위한 추가적 인 단계가 필요하므로 순응 과정에 많은 시간과 비용이 소비 될 수 있으며, 순응 방법에 따라서 아질산화 효율이 감소할 우려가 있다. 하지만, 일반하수 슬러지가 아닌 염분 환경의 미생물이나 염분폐수슬러지를 식종원으로 이용한다면, 염분 순응 과정 없이 고염분의 폐수처리에 적용 가능한 PN 공정을 보다 신속하고 안정적으로 유도할 수 있을 것이다. 염분농도 범위 30-50 g NaCl/L의 폐수 처리 연구에서 내염성 $\mathrm{AOB}$ 인 $N$. europaea 가 우점하였으며 ${ }^{23,24)}$, Guo 등 ${ }^{25)}$ 은 염분 농도 25 $\mathrm{g} \mathrm{NaCl} / \mathrm{L}$ 에서 내염성 $\mathrm{AOB}$ 인 N. europaea와 N. mobilis가 검출 되었다고 보고하였다. 하지만, 염분 환경의 미생물이나 염분 폐수슬러지를 식종원으로 이용한 PN 공정 연구는 많이 수행 되지 않았으며, 염분폐수슬러지에서 농화배양된 $\mathrm{AOB}$ 군집과 담수슬러지를 식종한 $\mathrm{PN}$ 공정의 $\mathrm{AOB}$ 군집을 비교한 연구 또한 드물다.

따라서, 본 연구에서는 하수처리장의 슬러지(하수슬러지)와 공동어시장 폐수처리장의 슬러지(염분폐수슬러지)를 각각 식 종원으로 이용하여 고염분 조건에서 고농도의 암모늄을 아질 산염으로 전환하는 PN 반응기를 운전하였다. 또한, 구축된 $\mathrm{PN}$ 반응기에서 식종원 종류에 따라 우점하는 $\mathrm{AOB}$ 군집의 변화를 비교하였다.

\section{2. 실험방법}

\section{1. 식종원 및 아질산화 반응기 운전}

하수슬러지와 염분폐수슬러지를 이용한 PN 반응기를 구축
하기 위하여 부산의 수영하수처리장 폭기조에서 채취한 슬러 지와 부산 자갈치 공동어시장 폐수처리시설의 폭기조에서 채 취한 슬러지를 식종원으로 사용하였다. 하수슬러지를 식종한 아질산화 반응기(PN1)는 유효부피 $4 \mathrm{~L}$ 의 원통형 반응기를 사용하여 연속회분식으로 운전되었다. PN1은 고농도 암모늄 $(500-3,000 \mathrm{mg} / \mathrm{L})$ 조건에서 아질산화 반응을 구축하였으며, 유입 암모늄의 $80 \%$ 이상이 아질산염으로 전환되었다. 농화배 양된 $\mathrm{AOB}$ 슬러지 $(2 \mathrm{~g} \mathrm{VSS} / \mathrm{L})$ 를 같은 크기와 형태의 반응기에 식종하여 유입 암모늄 농도 $300 \mathrm{mg} \mathrm{NH}{ }_{4}{ }^{+} \mathrm{N} / \mathrm{L}$ 에서 염분의 농도를 $20 \mathrm{~g} \mathrm{NaCl} / \mathrm{L}$ 까지 단계적으로 증가시키며 순응시켰다 (phase 1). 이후 유입하는 암모늄의 농도를 $500 \mathrm{mg} / \mathrm{L}$ 로 증가시 켜, 암모늄 부하(0.3-0.5 kg/m $/$ day)에 따른 아질산화 효율을 평가하였다(phase 2). 염분폐수슬러지 $(10 \mathrm{~g} \mathrm{VSS} / \mathrm{L})$ 를 식종한 아질산화 반응기(PN2)는 유효부피 $10 \mathrm{~L}$ 의 원통형 반응기를 사용하여 연속회분식으로 운전되었다. PN2 반응기에는 염분 순응 과정 없이 $20 \mathrm{~g} \mathrm{NaCl} / \mathrm{L}$ 염분을 바로 주입하였으며, 유입 암모늄 부하 $0.3 \mathrm{~kg} / \mathrm{m}^{3} / \mathrm{day}$ 에서 아질산화 반응을 유도하였다 (phase 1). 이후, 유입부하 상승에 따른 부분아질산화 효율을 평가하였다(phase 2).

두 반응기 모두 같은 성분의 인공폐수를 유입수로 사용하였 으며, 인공폐수의 조성은 $\left(\mathrm{NH}_{4}\right)_{2} \mathrm{SO}_{4} \quad 1,500-4,000 \mathrm{mg} / \mathrm{L}(300-800$ $\mathrm{mg} \mathrm{NH}_{4}{ }^{+}-\mathrm{N} / \mathrm{L}$ ), $\mathrm{NaHCO}_{3} 275-740 \mathrm{mg} / \mathrm{L}, \mathrm{KH}_{2} \mathrm{PO}_{4} 70 \mathrm{mg} / \mathrm{L}$, $\mathrm{CaCl}_{2} \cdot 2 \mathrm{H}_{2} \mathrm{O} 175 \mathrm{mg} / \mathrm{L}, \mathrm{MgSO} 4 \cdot 7 \mathrm{H}_{2} \mathrm{O} 125 \mathrm{mg} / \mathrm{L}, \mathrm{FeSO} 4 \cdot$ $7 \mathrm{H}_{2} \mathrm{O} 9 \mathrm{mg} / \mathrm{L}$, EDTA $6 \mathrm{mg} / \mathrm{L}$ 이었으며, 유입수의 초기 $\mathrm{pH}$ 는 7 이었다. 초기 유입 암모늄 부하가 약 $0.3 \mathrm{~kg} / \mathrm{m}^{3} / \mathrm{d}$ 가 되도록 유입 암모늄 농도를 조절하였으며, 세부적인 운전조건은 Table 1과 같다. 두 $\mathrm{PN}$ 반응기는 $30 \pm 1{ }^{\circ} \mathrm{C}$ 의 항온실에서 운전되었으며, 운전기간 동안 $\mathrm{pH}$ 조절은 없었고, $\mathrm{DO}$ 농도는 $1 \mathrm{mg} / \mathrm{L}$ 이상으로 유지하였다.

\section{2. 질소 화합물 분석 및 아질산화 효율 계산}

유입수와 유출수의 질소화합물 $\left(\mathrm{NH}_{4}{ }^{+}-\mathrm{N}, \mathrm{NO}_{2}{ }^{-}-\mathrm{N}, \mathrm{NO}_{3}{ }^{-}-\mathrm{N}\right)$ 농도는 수질분석키트(Humas Co. Ltd. Daejeon, Korea)를 이용 하여 분석하였다. $\mathrm{pH}$ 와 $\mathrm{DO}$ 의 측정에는 $\mathrm{pH}$ meter (Orion star, Thermo Scientific, singapore)와 DO meter (550 A, YSI incorporated, USA)를 각각 사용하였다.

각 반응기의 아질산화 효율을 평가하고 비교하기 위하여, 아질산염 축적 효율(nitrite accumulation efficiency, NAE), 암 모늄 제거 효율(ammonium removal efficiency, ARE), 암모늄 제거 속도(ammonium removal rate, ARR)를 각각 식 (1)-(3)을 통해 계산하였다.

$$
N A E(\%)=\frac{\left(N O_{2}^{-}-N\right)_{o u t}-\left(N O_{2}^{-}-N\right)_{i}}{\left(N H_{4}^{+}-N\right)_{i}-\left(N H_{4}^{+}-N\right)_{o u t}} \times 100
$$


Table 1. Operating condition of nitritation reactors, PN1 and PN2.

\begin{tabular}{ccc} 
Operating condition & PN1 & PN2 \\
Inoculum source & Sewage sludge & Saline wastewater sludge \\
\hline Influent $\mathrm{NH}_{4}{ }^{+}-\mathrm{N}$ loading rate $\left(\mathrm{kg} / \mathrm{m}^{3} /\right.$ day $)$ & $0.3-0.5$ & $0.1-0.3$ \\
\hline Influent NH$_{4}{ }^{+} \mathrm{N}(\mathrm{mg} / \mathrm{L})$ & $300-500$ & $600-800$ \\
\hline $\mathrm{HRT}(\mathrm{hr})$ & 24 & $48-96$ \\
\hline Influent salinity $(\mathrm{g} \mathrm{NaCl} / \mathrm{L})$ & $0-20$ & 20 \\
\hline Temperature $\left({ }^{\circ} \mathrm{C}\right)$ & 30 & 30 \\
\hline $\mathrm{DO}(\mathrm{mg} / \mathrm{L})$ & $>1$ & $>1$ \\
\hline $\mathrm{pH}$ & No control & No control
\end{tabular}

Table 2. PCR conditions to amplify V3-V4 regions of bacterial 16S rRNA sequence.

\begin{tabular}{|c|c|c|}
\hline Primer & Sequence $\left(5^{\prime}-3^{\prime}\right)$ & PCR conditions \\
\hline V3F & CCTACGGGAGGCAGCAG & $\begin{array}{l}\text { - Initial denaturation step: } 3 \text { min at } 95^{\circ} \mathrm{C} \\
\text { - PCR steps ( } 25 \text { cycles) } \\
\text { - denaturation: } 30 \mathrm{sec} \text { at } 95^{\circ} \mathrm{C}\end{array}$ \\
\hline V4R & GGACTACHVGGGTWTCTAAT & $\begin{array}{l}\text { - annealing: } 30 \mathrm{sec} \text { at } 55^{\circ} \mathrm{C} \\
\text { - extension: } 30 \mathrm{sec} \text { at } 72^{\circ} \mathrm{C} \\
\text { - Final extension step: } 5 \mathrm{~min} \text { at } 72^{\circ} \mathrm{C}\end{array}$ \\
\hline
\end{tabular}

$$
\begin{aligned}
& A R E(\%)=\frac{\left(N H_{4}^{+}-N\right)_{i}-\left(N H_{4}^{+}-N\right)_{o u t}}{\left(N H_{4}^{+}-N\right)_{i}} \times 100 \\
& A R R\left(k g / m^{3} / \text { day }\right)=\frac{\left(N H_{4}^{+}-N\right)_{i}-\left(N H_{4}^{+}-N\right)_{o u t}}{H R T}
\end{aligned}
$$

여기서, $\left(\mathrm{NO}_{2}^{-}-\mathrm{N}\right)_{\mathrm{i}}$ 은 유입 아질산염 농도 $(\mathrm{mg} / \mathrm{L}),\left(\mathrm{NO}_{2}^{-}-\mathrm{N}\right)_{\text {out }}$ 은 유출 아질산염 농도 $(\mathrm{mg} / \mathrm{L}),\left(\mathrm{NH}_{4}{ }^{+}-\mathrm{N}\right)$ 은 유입 암모늄 농도 $(\mathrm{mg} / \mathrm{L}),\left(\mathrm{NH}_{4}{ }^{+}-\mathrm{N}\right)_{\text {out }}$ 은 유출 암모늄 농도 $(\mathrm{mg} / \mathrm{L}), \mathrm{HRT}$ 은 수리 학적 체류시간(hr)이다.

\section{3. 미생물 군집 해석}

식종원에 따른 $\mathrm{AOB}$ 군집 변화를 관찰하기 위해서 반응기 내 미생물을 채취하였다. PN1의 경우, 식종원으로 사용한 하 수슬러지, 아질산화 농화배양 슬러지(염분순응 전 슬러지), 염 분순응 후 슬러지(반응기 운전 종료 후 슬러지)의 미생물군집 을 분석하였다. PN2의 경우에는 식종원으로 사용한 공동어시 장 폐수처리시설의 폭기조 슬러지, 반응기 운전 종료 후 슬러 지의 미생물군집을 분석하였다. 각 미생물 시료 $1 \mathrm{~mL}$ 에서 DNeasy ${ }^{\circledR}$ PowerSoil ${ }^{\circledR}$ Kit (QIAGEN Inc., Germany)를 사용하 여 $\mathrm{DNA}$ 를 추출하였으며, 추출된 $\mathrm{DNA}$ 의 순도와 정량은 Nanodrop (Thermo Fisher Scientific Inc., USA)을 이용하여 측정하였으며, $16 \mathrm{~S}$ rRNA의 V3-V4 region을 증폭하기 위하여 중합효소연쇄반응(Polymer chain reaction; PCR)을 수행하였 다(Table 2). 이후, illumina MiSeq 플랫폼을 활용하여 박테 리아의 염기서열을 분석하였으며(Macrogen Inc., Korea), Ultrafast Clustering Algorithms for Metagenomic Sequence Analysis를 이용하여 시퀸싱 오류(저품질 및 불명확한 염기서
열, chimera 등)를 제거한 후, $97 \%$ 이상의 유사성을 갖는 염기서 열끼리 클러스터화하여 종 수준의 조작분류단위(Operational taxonomic unit; OTU)를 도출하였다. 각 OTU의 대표 염기서 열은 National Center for Biotechnology Information (NCBI) 데이터베이스(https://ncbi.nlm.nih.gov)를 이용하여 유사성이 가장 높은 박테리아로 분류되었다. 식종원별 미생물 군집 간의 상관관계 및 다양성을 해석하기 위하여, QIIME (Ver 1.9)을 이용하여 미생물 군집 사이의 주성분 분석(Principal component analysis, PCA)과 종다양성 및 균등도(Shannon, Chao1, and Coverage index) 분석을 수행하였다.

\section{3. 결과 및 고찰}

\section{1. 식종원 종류에 따른 암모늄 전환 효율}

하수슬러지를 식종한 PN1 반응기는 넓은 범위의 높은 암모 늄 농도 $(500-3,000 \mathrm{mg} / \mathrm{L})$ 에서 $80 \%$ 이상의 안정적인 NAE를 나타냈다(Fig. 1). 하수슬러지는 고농도 암모늄을 안정적으로 아질산화 할 수 있는 PN 반응기 구축을 위한 식종원으로 적합 함을 알 수 있었다. 구축된 $\mathrm{AOB}$ 를 염분에 순응시키기 위하여 유입 암모늄 부하를 약 $0.3 \mathrm{~kg} / \mathrm{m}^{3} /$ day로 낮춘 상태에서 염분농 도를 $20 \mathrm{~g} \mathrm{NaCl} / \mathrm{L}$ 까지 단계적으로 증가시켰으며, 유출수의 암모늄 농도는 약 $60 \mathrm{mg} / \mathrm{L}$ 로 안정적으로 유지됨을 확인하였 다(phase 1). PN1에서 염분을 주입하기 이전의 최대 ARE와 $\mathrm{ARR}$ 은 각각 $90.8 \%, 0.51 \mathrm{~kg} / \mathrm{m}^{3} / \mathrm{d}$ 였으며, 염분 주입 후의 $\mathrm{ARE}$ 와 ARR은 각각 $86.7 \%, 0.29 \mathrm{~kg} / \mathrm{m}^{3} / \mathrm{d}$ 으로 약간 감소하였다 (Fig.2(a)). 유입부하 변화에 따른 아질산화 효율을 평가하기 위하여, 동일한 염분 농도 $(20 \mathrm{~g} \mathrm{NaCl} / \mathrm{L})$ 에서 유입 암모늄 부하 를 약 $0.5 \mathrm{~kg} / \mathrm{m}^{3} /$ day으로 증가시켜 운전하였다(phase 2). 질소 


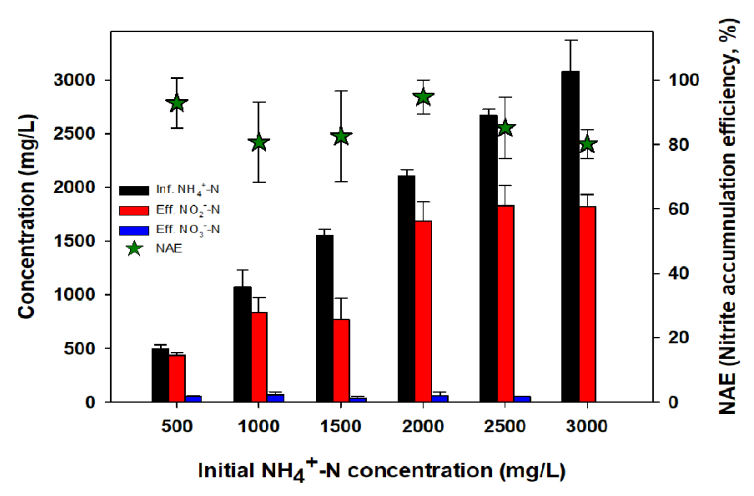

Fig. 1. Nitritation of high concentration ammonia in PN1 reactor inoculated with an activated sludge from a sewage treatment plant.

부하 상승에도 암모늄 전환은 안정적으로 이루어졌으나, 10 일 이후에 유출수 암모늄 농도가 증가하는 현상이 관찰되었다. 원인은 분명하지 않으나 반응기 내의 $\mathrm{pH}$ 가 6.0 까지 감소하였 으며, 낮은 $\mathrm{pH}$ 로 인하여 $\mathrm{AOB}$ 의 활성이 저해 받았기 때문으로 추측한다. 일반적으로 $\mathrm{AOB}$ 의 최적 $\mathrm{pH}$ 범위는 7-8.5이며, $\mathrm{pH}$ 6.5 이하에서는 암모늄 산화반응이 잘 일어나지 않는다. ${ }^{26,27}$ 하지만, 운전이 진행됨에 따라 반응기 내의 $\mathrm{pH}$ 가 회복되어 7.3 정도에서 안정적으로 유지되었으며, 이에 따라 $\mathrm{ARE}$ 은 $99 \%, \mathrm{ARR}$ 은 $0.51 \mathrm{~kg} / \mathrm{m}^{3} /$ day 까지 증가하였다(Fig. 2(a)).

염분폐수슬러지를 식종한 반응기 PN2는 염분 순응 과정 없이 염분 농도 $20 \mathrm{~g} \mathrm{NaCl} / \mathrm{L}$ 및 유입 암모늄부하 $0.1 \mathrm{~kg} / \mathrm{m}^{3} / \mathrm{day}$ 에서 아질산화반응을 유도하였다. PN1보다 ARE의 변동이 크 게 나타났지만, 운전 30 일 이후부터 고농도 $(600 \mathrm{mg} / \mathrm{L})$ 로 주입 된 암모늄이 안정적으로 제거되었으며, $\mathrm{ARE}$ 와 ARR은 각각 $82.1 \%, 0.21 \mathrm{~kg} / \mathrm{m}^{3} / \mathrm{d}$ 이었다(Fig. 2(b)). 유입 암모늄 부하를 0.3 $\mathrm{kg} / \mathrm{m}^{3} / \mathrm{day}(800 \mathrm{mg} / \mathrm{L}$ )로 증가시키더라도(운전 53일), 유출수 아질산염 농도는 약 $435 \mathrm{mg} / \mathrm{L}$ 으로 유지되었으며, 약 $62 \%$ 의 $\mathrm{NAE}$ 를 달성하였다. 따라서, 본 실험에 사용한 하수슬러지와 염분폐수슬러지는 모두 고염분 조건에서 고농도 암모늄의 아 질산화를 위한 PN 반응기의 식종원으로 사용할 수 있음을 확인하였다. 추후 PN과 ANAMMOX 공정의 연계 운영의 효 율을 위하여 두 반응기의 장기 운전을 통해 암모늄과 아질산 염 비율 유지 및 안정성 평가가 필요할 것으로 판단된다.

\section{2. 식종원 종류에 따른 미생물 군집 변화}

하수슬러지를 식종한 PN1 반응기과 염분폐수슬러지를 식 종한 PN2의 미생물군집은 운전 기간 동안 $\mathrm{AOB}$ 의 농화배양 과정에서 OTU 개수, Chaol index, Shannon index 등의 종다양 성 지수가 감소하였다(Table 3). 고염분 조건의 아질산화과정 에서 특정 미생물군집이 우점하게 된 것으로 보인다. 특히, $\mathrm{AOB}$ 를 먼저 농화배양한 뒤에 염분에 순응시킨 PN1의 경우, $\mathrm{AOB}$ 의 농화배양 과정에서 $\mathrm{OTU}$ 개수와 종다양성 지수가 급 격하게 감소하였다. 반면 염분에 이미 순응된 염분폐수슬러지
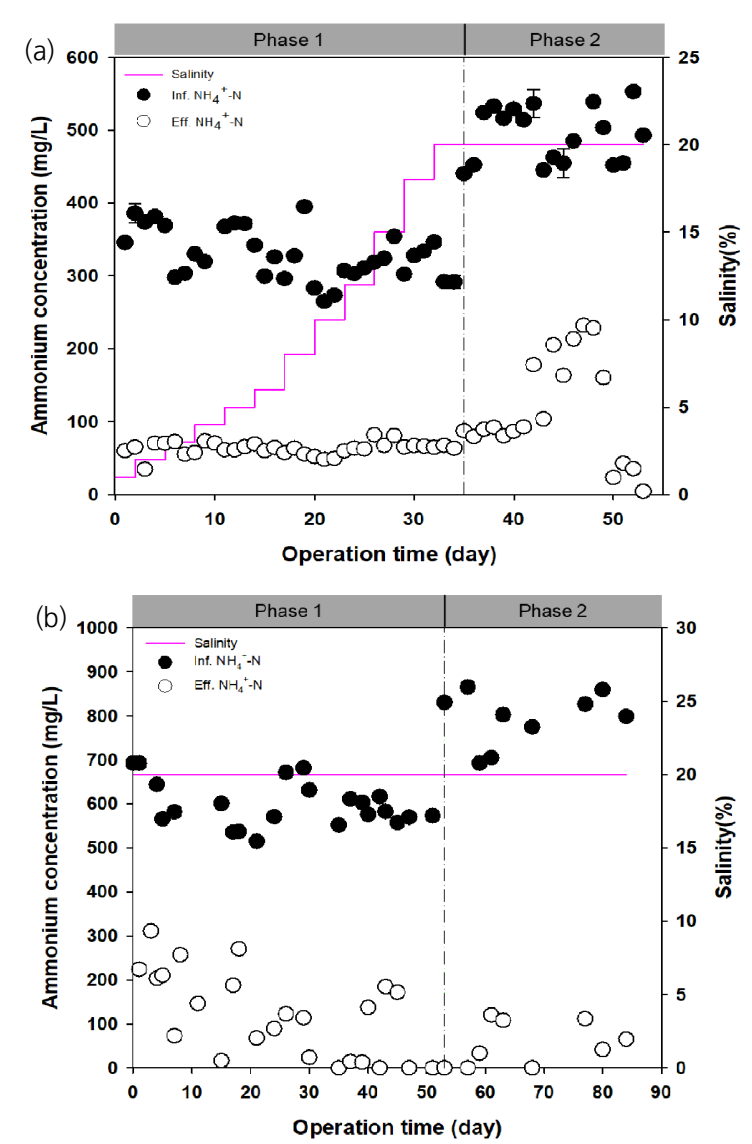

Fig.2. Ammonium removal under high salinity conditions in PN1 (a) and PN2 (b).

를 이용하여 $\mathrm{AOB}$ 를 농화배양한 PN2에서는 상대적으로 미생 물 군집의 다양성 변화가 적었으며 하수슬러지로부터 농화배 양된 $\mathrm{AOB}$ 군집에 비해 종다양성이 높았다. 따라서 하수슬러 지를 식종원으로 이용할 경우, $\mathrm{AOB}$ 의 농화배양 과정에서 미 생물군집의 다양성이 크게 낮아질 수 있으며, 이는 공정의 안정성을 낮출 우려가 있다. 부하율 변동을 포함한 다양한 운전환경의 변화가 공정의 안정성에 미치는 영향을 장기적인 운전을 통하여 확인할 필요가 있다.

$\mathrm{AOB}$ 의 농화배양 과정과 염분 순응 과정에서 미생물의 종다 양성 뿐만 아니라 우점하는 미생물군집 또한 크게 변화하였 다. PN1의 식종원에서는 Firmicute (30.9\%), Actinobacteria (30.2\%), Proteobacteria (25.1\%)가 상대적으로 높은 분율을 차지하고 있었으며, Bacteroidetes (6.9\%)와 Planctomycetes (1.4\%)는 상대적으로 낮은 분율을 보였다(Fig. 3). 하지만, $\mathrm{AOB}$ 의 농화배양이 진행되면서 Proteobacteria 분율은 $68.6 \%$ 로 증가하였으며, Bacteroidetes와 Deinococcus-Thermus 분율이 $10 \%$ 대로 증가하였다. 반면, Actionbacteria와 Firmicutes는 $4 \%$ 로 감소하였다. 염분 순응 후에는 Proteobacteria의 분율 은 76.7\%로 더 증가하였으며, Acidobacteria, Bacteroidetes, Deinococcus-Thermus 의 분율은 각각 $5 \%, 9.6 \%, 7.6 \%$ 로 큰 변화 는 없었지만, Firmictues의 분율은 $0.4 \%$ 로 감소하였다. 
Table 3. Microbial diversity changes between inoculum source and nitritation enrichment culture in PN1 and PN2 reactor.

\begin{tabular}{|c|c|c|c|c|c|c|}
\hline Reactor & Sample name & Read count & OTU & Chao1 & Shannon & Goods coverage \\
\hline \multirow{3}{*}{ PN1 } & Inoculum & 11,807 & 200 & 202 & 5.16 & 0.99 \\
\hline & PN & 20,362 & 72 & 84 & 3.49 & 0.99 \\
\hline & $\mathrm{PN}+$ salt & 20,185 & 74 & 91 & 2.47 & 0.99 \\
\hline \multirow{2}{*}{ PN2 } & Inoculum & 17,096 & 171 & 187 & 4.89 & 0.99 \\
\hline & PN+salt & 16,577 & 158 & 166 & 4.21 & 0.99 \\
\hline
\end{tabular}

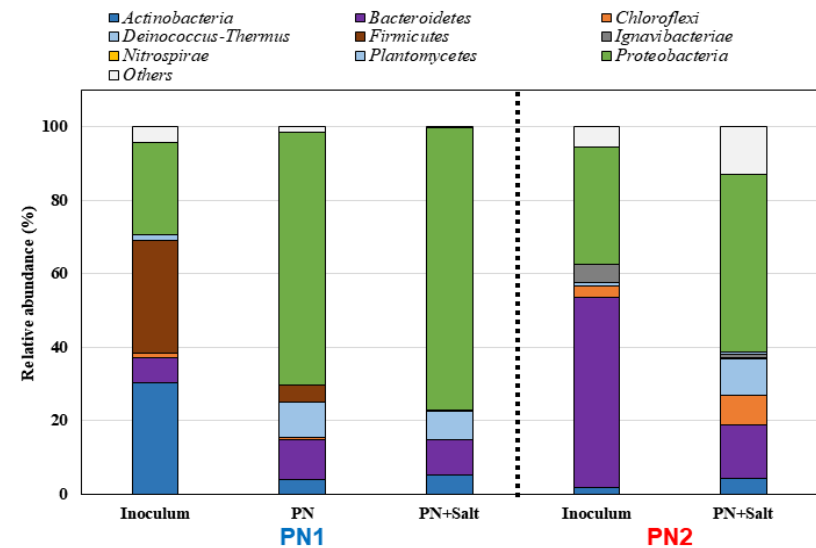

Fig. 3. Changes of the phylum-level microbial community in PN1 and PN2 during the $A O B$ enrichment cultivation under high saline condition.

염분폐수슬러지를 식종원으로 이용한 PN2의 경우, 식종원 에서는 Proteobacteria (31.7\%)와 Bacteoridetes (52\%)가 상 대적으로 높은 분율을 나타냈다(Fig.3). 하지만, AOB 농화 배양 이후 Proteobacteria의 분울은 $48.3 \%$ 로 증가하였으나, Bacteroidetes는 $14.3 \%$ 으로 크게 감소하였다. 또한, DeinococcusThermus (10\%), Chloroflexi (8.1\%)의 분율이 약간 증가하 였다.

PN1과 PN2 반응기의 식종원은 달랐고, 순응방법에도 차이 는 있었지만, 문(phylum) 수준에서는 유사한 경향을 보였다. 모든 반응기에서 Proteobacteria가 가장 높은 분율을 차지하였 다. 이는 농화배양 과정에서 Proteobacteria에 속하는 AOB가 우점화되었기 때문으로 생각되며, 우점하는 $\mathrm{AOB}$ 군집의 변 화에 대해서는 아래 3.3절에서 자세히 설명하였다.

PN1과 PN2 미생물군집의 속(genus) 수준의 변화를 비교한 PCA 결과에서도 유사한 경향을 확인할 수 있다(Fig.4). PN1과 $\mathrm{PN} 2$ 반응기 식종원의 미생물 군집은 큰 차이를 보였지만, $\mathrm{AOB}$ 의 농화배양 과정에서 두 반응기의 속 수준에서의 미생 물 군집이 상대적으로 가까워지는 경향을 나타내었다. 또한, 염분 순응 과정에 비해 $\mathrm{AOB}$ 농화배양 과정에서 미생물군집 변화가 심한 것으로 미루어, 농화배양된 아질산화 관련 미생 물들은 염분에 내성이 있거나 쉽게 순응할 수 있는 특성을 가진 것으로 보인다.

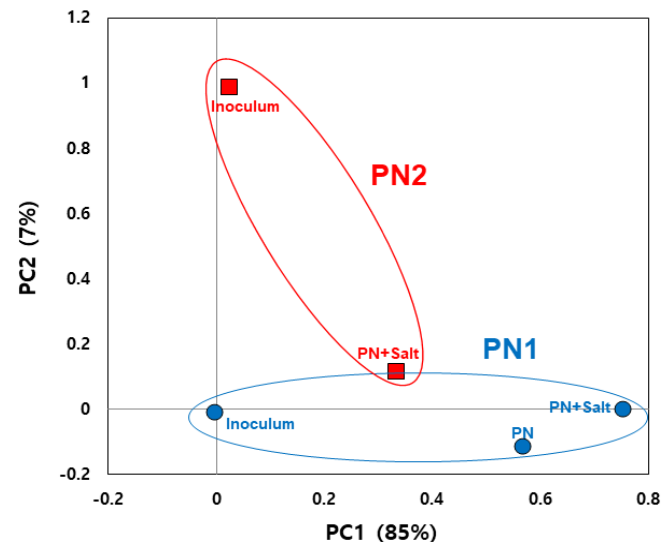

Fig.4. Principal component analysis based on the genus-level microbial communities in PN1 and PN2.

\begin{tabular}{|c|c|c|c|c|c|c|}
\hline & & & & \multirow[b]{2}{*}{0} & \multicolumn{2}{|c|}{ Relative abundance (\%) } \\
\hline & & & & & 1 & $5 \quad 10$ \\
\hline \multirow{2}{*}{ Species } & \multicolumn{3}{|c|}{ PN1 } & \multicolumn{2}{|c|}{ PN2 } & \multirow{2}{*}{ Function } \\
\hline & Inoculum & PN & PN+Salt & Inoculum & PN+Salt & \\
\hline Nitrosomonas eutropha & & & & & & Ammonium oxidation \\
\hline Nitrosomonas halophila & & & & & & Ammonium oxidation \\
\hline Nitrosomoans sterocoris & & & & & & Ammonium oxidation \\
\hline Nitrosomonas communis & & & & & & Ammonium oxidation \\
\hline Nitrospira moscoviensis & & & & & & Nitrite oxidation \\
\hline
\end{tabular}

Fig. 5. Relative abundance of key functional bacteria for ammonia oxidation and nitrite oxidation in PN1 and PN2.

\section{3. 식종원 종류에 따른 우점 질산화 미생물의 변화}

$\mathrm{PN} 1$ 반응기의 식종원으로 사용한 하수슬러지에서는 $\mathrm{AOB}$ 인 Nitrosomonas communis가 $0.03 \%$, NOB인 Nitrospira moscoviensis 가 $0.03 \%$ 검출되었으나, $\mathrm{AOB}$ 농화배양 후에는 Nitrosomonas halophila (22.8\%)와 N. stercoris (3.5\%)가 우점 하였고 $\mathrm{NOB}$ 는 검출되지 않았다. 하지만, 염분 순응 이후에는 $\mathrm{AOB}$ 농화배양 과정에서 발견되었던 2 종 모두 급격하게 감소 하였고, 대신 N. eutropha의 분율이 $60.7 \%$ 까지 증가하였다 (Fig.5). 선행연구에서 활성슬러지를 식종원으로 이용하여 아 질산화 반응을 유도하고 염분농도를 단계적으로 증가시킨 PN 공정과 염분 순응 후에 아질산화 반응이 유도된 PN 공정 모두 에서 N. eutropha가 우점하였다. ${ }^{22,28)}$ 따라서, 하수슬러지를 이 용하여 고농도 염분 조건에서 고농도 암모늄을 아질산화하는 경우에는 N. eutropha가 우선적으로 성장하게 되는 것으로 보 
인다.

PN2 반응기에서는 PN1과 완전히 다른 경향을 보였다. 식종 원으로 사용한 염분폐수슬러지에서는 N. eutropha가 $1.2 \%$, N. halophila가 $0.9 \%$ 존재하였으나, $\mathrm{AOB}$ 농화배양 이후의 미생물군집에서는 N. eutropha는 $0.6 \%$ 까지 감소하였고, $N$. halophila가 $20.2 \%$ 까지 증가하였다(Fig.5). 이는 식종원의 종 류 및 아질산화 미생물 농화배양 과정에 따라서 우점하는 $\mathrm{AOB}$ 의 종이 달라질 수 있음을 의미한다.

일반적으로 고농도의 암모늄은 $\mathrm{AOB}$ 성장을 저해하는 것으 로 알려져 있지만 ${ }^{16}$, N. eutropha는 세포 성장에 염분이 필요 없음에도 불구하고 염분이 있는 곳에서 성장이 가능한 내염성 (halotolerant) $\mathrm{AOB}$ 이며, 질소농도가 높은 부영양 환경에서 잘 서식한다. ${ }^{16,18)}$ N. stercoris는 고농도 암모늄과 염분에 대한 내 성이 있으며 ${ }^{16}, N$. halophila는 세포 성장에 반드시 염분이 필 요한 호염성 $\mathrm{AOB}$ 로서, 질소농도가 높은 부영양 환경에서도 잘 서식한다. ${ }^{18,29)}$ 본 연구에서는 고염분 및 고농도 암모늄 아 질산화 과정에서 하수슬러지를 식종원으로 이용한 PN1에서 는 N. eutropha가 우점하였고, 염분폐수슬러지를 이용한 PN2 에서는 N. halophila가 우점하였다. 따라서 고농도 질소 및 염분 환경에서는 N. eutropha와 N. halophila 모두 잘 성장하지 만, 하수슬러지의 경우에는 염분에 내성이 있는 N. eutropha 가, 염분폐수슬러지의 경우에는 호염성의 N. halophila가 우점 하는 것으로 보인다.

\section{4. 결 론}

본 연구에서는 고농도 염분 조건에서 고농도 암모늄을 효율 적으로 아질산염으로 산화하는 PN공정의 구축에 효과적인 식종원을 탐색하기 위하여, 하수처리장의 슬러지를 식종한 반응기(PN1)와 공동어시장 폐수처리장의 슬러지를 식종한 반응기(PN2)를 이용하여 아질산화 미생물의 농화배양 과정 에서 변화하는 미생물군집과 우점하는 $\mathrm{AOB}$ 군집을 비교하 였다.

1) 하수처리장의 슬러지와 공동어시장 폐수처리장의 슬러 지 모두 농화배양을 통하여 염분조건 $(20 \mathrm{~g} \mathrm{NaCl} / \mathrm{L})$ 에서 최대 $60 \%$ 이상의 $\mathrm{NAE}$ 를 나타내어 성공적으로 $\mathrm{PN}$ 을 구축할 수 있었다.

2) 두 반응기 모두에서 $\mathrm{AOB}$ 농화배양 및 염분 순응 과정을 통하여 미생물 종다양성은 감소하였으나, Proteobacteria의 분율 (PN1: $76.7 \%, \mathrm{PN} 2: 48.3 \%$ )이 가장 높게 나타났다.

3) PN1 (N. eutropha, 60.7\%)과 PN2 (N. haophila, 20.2\%)에서 각각 다른 $\mathrm{AOB}$ 가 우점화되었지만, 하수처리장의 슬러지와 어시장 폐수처리장의 슬러지 모두 고염분 암모늄을 처리하는 $\mathrm{PN}$ 공정 구축을 위한 식종원으로 사용할 수 있을 것으로 보인다.

\section{Acknowledgements}

이 논문은 부산대학교 기본연구지원사업(2년)과 한국연구 재단 4단계 BK21 사업의 스마트 해양도시 인프라 교육연구단 과제(4199990614525)에 의하여 연구되었습니다. 이에 감사드 립니다.

\section{References}

1. Ministry of Environment, A Comprehensive Plan for the Inland Treatment and Energy Recovery of Wastewater from Food Waste Treatment, Ministry of Environment, pp. 7-8 (2007).

2. J. P. Lee, S. C. Park, S. W. Rhee, The effect of ammonia and sodium chloride on the anaerobic degradation of food waste, J. Korean Soc. Environ. Eng., 19(9), 1185-1192(1997).

3. K. H. Lee, S. Y. Lee, S. G. Cheon, J. S. Kim, D. J. Park, D. H. Lee, J. H. Sim, S. J. Bae, Study on Food Wastewater Treatment by using Leachate Recirculation Landfill, Sudokwon Landfill Site Management Corporation(2012).

4. Ministry of Environment and National Institute of Environmental Research, Technical Guideline for Combined Treatment Biogasification Facility, Ministry of Environment and National Institute of Environmental Research(2015).

5. R. C. Jin, G. F. Yang, J. J. Yu, P. Zheng, The inhibition of the anammox process: a review, Chem. Eng. J., 197, 67-79 (2012).

6. H. Chen, C. Ma, Y. X. Ji, W. M. Ni, R. C. Jin, Evaluation of the efficacy and regulation measures of the anammox process under salty conditions, Sep. Purif. Technol., 132, 584-592(2014).

7. B. S. Xing, Q. Guo, G. F. Yang, Z. Z. Zhang, P. Li, L. X. Guo, R. C. Jin, The properties of anaerobic ammonium oxidation (anammox) granules: roles of ambient temperature, salinity and calcium concentration, Sep. Purif. Technol., 147, 311-318(2015).

8. H. G. Kim, D. H. Ahn, The effects of high salinity on nitrogen removal and the formation characteristics of aerobic granular sludge, Environ. Eng. Res., 25(5), 659-667(2020).

9. B. Wett, Development and implementation of a robust deammonification process, Water Sci. Technol., 56(7), 81-88 (2007).

10. S. Lackner, E. M. Gilbert, S. E. Vlaeminck, A. Joss, H. Horn, M. C. M. van Loosdrecht, Full-scale partial nitritation/anammox experiences - an application survey, Water Res., 55, 292-303 (2014).

11. G. T. Daigger, Oxygen and carbon requirements for biological nitrogen removal processes accomplishing nitrification, nitritation, and anammox, Water Environ. Res., 86(3), 204-209 (2014).

12. M. Strous, E. Van Gerven, P. Zheng, J. G. Kuenen, M. S. M. Jetten, Ammonium removal from concentrated waste streams with the anaerobic ammonium oxidation (anammox) 
process in different reactor configurations, Water Res., 31(8), 1955-1962(1997).

13. Y. Qin, Y. Cao, J. Ren, T. Wang, B. Han, Effect of glucose on nitrogen removal and microbial community in anammoxdenitrification system, Bioresour. Technol., 244(Part 1), 33-39(2017).

14. Y. H. Park, J. M. Kim, W. Y. Choi, J. C. Yu, T. H. Lee, Sidestream deammonification, J. Korean Soc. Water Environ., 34(1), 109-120(2018).

15. K. M. Jo, Y. H. Park, S. J. Cho, T. H. Lee, Variation of nitrogen removal efficiency and microbial communities depending on operating conditions of a CANON process, J. Korean Soc. Environ. Eng., 37(6), 332-339(2015).

16. T. Nakagawa, R. Taahashi, Nitrosomonas stercoris sp. nov., a chemoautotrophic ammonia-oxidizing bacterium tolerant of high ammonium isolated from composted cattle manure, Microbes Environ., 3(3), 221-227(2015).

17. P. Kunapongkiti, C. Rongsayamanont, P. Nayramitsattha, T. Limpiyakorn, Application of cell immobilization technology to promote nitritation: a review, Environ. Eng. Res., 25(6), 807-818(2020).

18. H. P. Koops, A. Pommerening-Roser, Distribution and ecophysiology of the nitrifying bacteria emphasizing cultured species, FEMS Microbiol. Ecol., 37(1), 1-9(2001).

19. N. T. Minh, M. Choi, N. Park, H. Bae, Critical design factors for polyvinyl alcohol hydrogel entrapping ammonia-oxidizing bacteria: biomass loading, distribution of dissolved oxygen, and bacterial liability, Environ. Eng. Res., 26(2), 200010 (2020).

20. Y. Sun, L. Xin, G. Wu, Y. Guan, Nitrogen removal, nitrous oxide emission and microbial community in sequencing batch and continuous-flow intermittent aeration processes, Environ. Eng. Res., 24(1), 107-116(2019).

21. C. Wan, X. Yang, D. J. Lee, X. Liu, S. Sun, C. Chen, Partial nitrification of wastewaters with high $\mathrm{NaCl}$ concentrations by aerobic granules in continuous-flow reactor, Bioresour. Technol., 152, 1-6(2014).

22. M. S. Moussaa, D. U. Sumanasekera, S. H. Ibrahim, H. J. Lubberding, C. M. Hooijmans, H. J. Gijzen, M. C. M. van Loosdrecht, Long term effects of salt on activity, population structure and floc characteristics in enriched bacterial cultures of nitrifiers, Water Res., 40(7), 1377-1388(2006).

23. D. Jeong, K. Cho, C. Lee, S. Lee, H. Bae, Effects of salinity on nitrification efficiency and bacterial community structure in a nitrifying osmotic membrane bioreactor, Process Biochem., 73, 132-141(2018).

24. X. Huang, W. Mi, H. Ito, Y. Kawagoshi, Probing the dynamics of three freshwater anammox genera at different salinity levels in a partial nitritation and anammox sequencing batch reactor treating landfill leachate, Bioresour. Technol., 319, 124112 (2021).

25. Y. Guo, T. Sugano, Y. Song, C. Xie, Y. Chen, Y. Xue, Y. Y. Li, The performance of freshwater one-stage partial nitritation/anammox process with the increase of salinity up to $3.0 \%$, Bioresour. Technol., 311, 123489(2020).
26. S. M. Alison, J. I. Prosser, Ammonia oxidation at low $\mathrm{pH}$ by attached populations of nitrifying bacteria, Soil Biol. Biochem., 25(7), 935-941(1993).

27. S. A. Q. Burton, J. I. Prosser, Autotrophic ammonia oxidation at low $\mathrm{pH}$ through urea hydrolysis, Appl. Environ. Microbiol., 67(7), 2952-2957(2001).

28. J. P. Bassin, R. Kleerebezem, G. Muyzer, A. S. Rosado, M. C. M. van Loosdrecht, M. Dezotti, Effect of different salt adaptation strategies on the microbial diversity, activity, and settling of nitrifying, Appl. Microbiol. Biotechnol., 93(3), 1281-1294(2012).

29. H. P. Koops, B. Bottcher, U. C. Moller, A. PommereningRoser, G. Stehr, Classification of eight new species of ammonia-oxidizing bacteria: Nitrosomonas communis sp. nov., Nitrosomonas ureae sp. nov., Nitrosomonas aestuarii sp. nov., Nitrosomonas marina sp. nov., Nitrosomonas nitrosa sp. nov., Nitrosomonas eutropha sp. nov., Nitrosomonas oligotropha sp. nov. and Nitrosomonas halophila sp. nov., Microbiology, 137(7), 1689-1699(1991).

\section{Declaration of Competing Interest}

The authors declare that they have no known competing financial interests or personal relationships that could have appeared to influence the work reported in this paper.

\section{Authors and Contribution Statement}

\section{Jeongmi Kim}

Department of Civil and Environmental Engineering, Pusan National University, Ph.D. Student, ORCID (1) 0000-0001-6593-3889: Conceptualization, Data curation, Data analysis, Methodology, Validation, Visualization, Writing - original draft.

\section{Jaecheul Yu}

Department of Civil and Environmental Engineering, Pusan National University, Research Professor, ORCID () 0000-0002-9752-3435: Conceptualization, Project administration, Validation, Writing review and editing.

\section{Soyeon Jeong}

Department of Civil and Environmental Engineering, Pusan National University, Ph.D. Student, ORCID (1) 0000-0001-9041-532X: Conceptualization, Data curation, Data analysis, Methodology, Visualization.

\section{Yeonju Kim}

Department of Civil and Environmental Engineering, Pusan National University, M.S. Student, ORCID () 0000-0003-0844-1559: Data curation, Data analysis, Visualization. 


\section{Hyokwan Bae}

Department of Civil and Environmental Engineering, Pusan National University, Professor, ORCID (1) 0000-0002-2422-9411:

Validation, Writing - review and editing.

\section{Taeho Lee}

Department of Civil and Environmental Engineering, Pusan National University, Professor, ORCiD(1) 0000-0002-3450-4472:

Conceptualization, Funding acquisition, Project administration, Resources, Supervision, Writing - review and editing. 